\title{
CORAL BLEACHING, KARANG HIDUP ATAU MATI?
}

\author{
Qinthan Azzahra Aulia ${ }^{1 *}$ \& Ni Wayan Purnama Sari² \\ ${ }^{1}$ Program Studi Ilmu Kelautan, Fakultas Perikanan dan Ilmu Kelautan, Universitas Diponegoro \\ ${ }^{2}$ Pusat Penelitian Oseanografi, Lembaga Ilmu Pengetahuan Indonesia \\ *Alamat email: qinthanazzahra@gmail.com
}

\begin{abstract}
Coral reef ecosystem is one of the coastal marine ecosystems in tropical waters. Coral reef ecosystems are vulnerable to damage mainly due to environmental factors. A fairly popular event of coral reef damage is coral bleaching. Mass coral bleaching is generally caused by changes in Sea Surface Temperature (SST). The condition of corals that have bleaching is different from the condition of corals that have died. The recovery process from coral bleaching phenomena can be effectively carried out if the surrounding environment is supportive and sea surface temperature return stable. The phenomenon of coral bleaching is a real indicator of the environmental stresses that occur on coral reefs. This paper will explain about coral bleaching, the factors that cause coral bleaching, and whether the bleaching coral reefs mean alive or dead.
\end{abstract}

Keywords: coral bleaching, coral reefs, recovery.

\section{PENDAHULUAN}

Indonesia merupakan negara kepulauan terbesar di dunia, dengan panjang garis pantai lebih dari $81.000 \mathrm{~km}$ dan memiliki lebih dari 17.508 pulau. Indonesia juga memiliki bentang terumbu karang yang luas dan mampu melindungi garis pantai kepulauan Indonesia (Bengen, 1999; Santoso \& Kardono, 2008). Terumbu karang alami memiliki peran penting dalam mendukung kelestarian sumberdaya ikan dan organisme laut. Selain itu, terumbu karang berfungsi sebagai pelindung pantai dari aktivitas gelombang dan arus (Suharsono, 1998; Santoso \& Kardono, 2008).

Terumbu karang adalah kumpulan hewan karang yang membentuk struktur terumbu di dasar laut (Gambar 1). Struktur terumbu karang berasal dari deposit kalsium karbonat $\left(\mathrm{CaCO}_{3}\right)$ di laut yang dihasilkan oleh hewan karang (Papu, 2011). Karang merupakan hewan yang tidak memiliki tulang belakang dan termasuk Filum Coelenterata atau Cnidaria. Hewan karang berbentuk seperti tabung dan memiliki mulut yang dikelilingi tentakel. Hewan karang mencakup Ordo Scleractinia, Sub kelas Octocorallia, Kelas Anthozoa maupun Kelas Hydrozoa (Veron, 2000; Siringoringo, 2007).

Ekosistem terumbu karang adalah salah satu ekosistem laut pesisir yang berada di perairan daerah tropis. Ekosistem ini memiliki produktivitas yang tinggi, demikian juga dengan keanekaragaman hayatinya. Terumbu karang yang sehat memiliki banyak manfaat bagi ekonomi lokal masyarakat pesisir. Manfaat tersebut berupa penambahan stok ikan karang, aktivitas pariwisata menyelam, dan perlindungan ekosistem pesisir (Lutz et al., 2014; Sari, 2016).

Ekosistem terumbu karang rentan terhadap kerusakan, terutama akibat dari faktor lingkungan. Burke et al. (2002) 


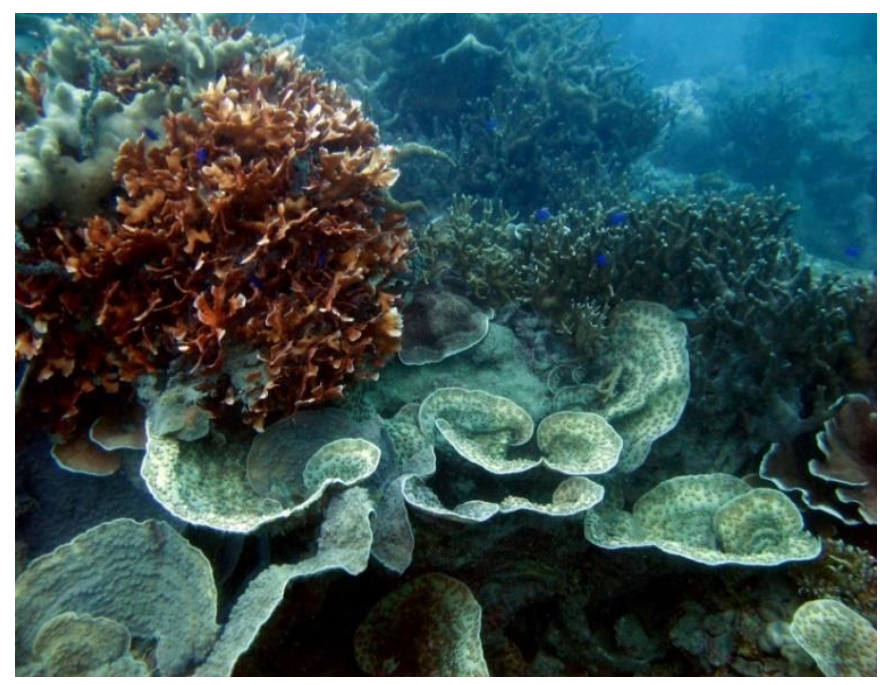

Gambar 1. Terumbu karang di Kepulauan Karimunjawa (dokumen pribadi, 2019).

dalam Fachrurrozie et al. (2012), menyatakan bahwa kerusakan terumbu karang dapat disebabkan oleh adanya sedimentasi dan pencemaran lingkungan. Menurut Harvell et al. (2007) dalam Aldyza \& Afkar (2015), kerusakan terumbu karang juga dapat terjadi akibat adanya pertumbuhan alga dan gangguan kesehatan yang memberi dampak buruk bagi pertumbuhan karang. Selain itu, menurut Rudi (2012) kerusakan terumbu karang juga dapat disebabkan oleh naik-turunnya suhu permukaan laut (SPL).

Peristiwa yang cukup popular dari kerusakan terumbu karang yaitu pemutihan karang atau coral bleaching. Pemutihan terumbu karang yaitu peristiwa terganggunya hubungan simbiosis antara karang dan algae endosimbion karang. Sebuah penelitian yang dilakukan oleh Fine et al. (2002), mengatakan bahwa pada tahun 2000 peristiwa pemutihan karang terjadi di seluruh dunia yang berdampak pada kematian karang dan kehancuran ekosistem terumbu karang yang belum pernah terjadi sebelumnya. Hal itu menyebabkan kekhawatiran para ilmuwan dan manajer sumber daya (HoeghGuldberg, 1999; Wilkinson, 1999, 2000;
Fine et al., 2002), sehingga menimbulkan spekulasi dari para pengamat tentang masa depan terumbu karang dalam menghadapi kenaikan suhu permukaan air laut (SST) sebagai salah satu konsekuensi dari pemanasan global (McClanahan et al., 2004).

\section{CORAL BLEACHING}

Iklim secara umum merupakan hasil dari interaksi proses-proses fisik dan kimia. Proses-proses tersebut memiliki parameter seperti suhu, kelembaban, angin, dan pola curah hujan yang terjadi di suatu tempat di bumi. Iklim terjadi akibat dari pemerataan energi bumi yang tidak tepat. Hal itu dikarenakan adanya perputaran atau revolusi bumi dan rotasi bumi. Revolusi dan rotasi bumi dapat menyebabkan radiasi matahari yang diterima berubah, sesuai lokasi dan posisi geografi suatu daerah. Posisi lintang suatu tempat dapat menjadi faktor utama yang menentukan iklim di tempat tersebut (Hasanudin, 1997; Surinati, 2008).

Ekosistem pesisir memiliki peran penting sebagai penyerap dan penyimpan karbon yang efektif. Karbon disebut sebagai penyebab dari rusaknya lapisan 
ozon, yang dapat menyebabkan terjadinya pemanasan global dan perubahan iklim. Keberadaan karbon di udara dalam jumlah banyak dapat berdampak negatif bagi lingkungan, terutama pada ekosistem terumbu karang (Field et al., 1998; Sari, 2016).

Kerusakan ekosistem terumbu karang dapat dilihat dari kerusakan secara fisik dan fisiologisnya. Kerusakan fisik pada karang meliputi koloni karang yang hancur, cabang yang patah, dan koloni yang terangkat dari substratnya. Sedangkan kerusakan fisiologis pada karang meliputi perubahan warna karang yang memudar bahkan memutih atau bleaching. Perubahan warna yang memudar pada karang terjadi akibat berkurangnya konsentrasi pigmen fotosintesis zooxanthellae pada polip karang (Suharsono, 1998; Fachrurrozie et al., 2012). Polip karang yang terlepas dari host membuat karang akan kehilangan sebagian besar pigmen warna dan jaringan lunaknya. Hal ini karena zooxanthellae sebagai penyumbang pigmen pada karang, ikut terlepas bersama polip karang tersebut (Wilkinson, 2000; Siringoringo, 2007).

Peristiwa pemutihan karang atau coral bleaching merupakan dampak dari karang yang mengalami tekanan atau stres lingkungan. Hal itu dapat berupa hilangnya simbion intertentakular dinoflagellata (Symbiodinium) atau pigmen fotosintesis. Coral bleaching terjadi ketika karang mengalami tekanan dalam skala spasial yang luas. Pemutihan karang juga terjadi akibat dari suhu hangat air laut dalam waktu lebih lama (De'ath et al., 2009; Ainsworth et al., 2016). Intensitas dan frekuensi dari pemutihan karang diperkirakan akan mengalami peningkatan. Hal itu karena suhu permukaan air laut atau Sea Surface Temperature (SST) yang terus meningkat akibat dari perubahan iklim secara global (Hooidonk et al., 2013 dan Ortiz et al., 2014; Ainsworth et al., 2016).

Peristiwa pemutihan karang menandakan bahwa terdapat kondisi lingkungan yang tidak baik untuk kehidupan karang, sehingga banyak spesies karang yang mengalami stres (Douglas, 2003; Setiawan et al., 2017). Kondisi lingkungan tersebut meliputi perubahan suhu air laut, radiasi matahari, sedimentasi, masukan air tawar, kontaminasi atau toksik dan penyakit (Brown, 1997; Setiawan et al., 2017).

Peristiwa pemutihan karang dalam skala besar atau coral bleaching massal umumnya disebabkan oleh adanya perubahan Suhu Permukaan Laut (SPL). Adapun peristiwa pemutihan karang dalam skala kecil yang umumnya disebabkan karena tekanan langsung dari manusia. Awal tahun 2010 menjadi waktu yang cukup panas dan suhu permukaan laut di beberapa tempat mengalami kenaikan. Naiknya suhu permukaan laut tersebut membentuk sejumlah hot spots yang dapat menyebabkan pemutihan pada karang (Rudi, 2012).

Peristiwa pemutihan karang merupakan indikator nyata mengenai tekanan lingkungan yang terjadi pada terumbu karang. Tekanan lingkungan yang dimaksud salah satunya seperti peningkatan suhu permukaan laut selama El Nino (Tomascik et al., 1997; Setiawan et al., 2017). Kejadian El Nino terakhir yaitu terjadi tahun 2015-2016 yang merupakan kejadian terkuat yang pernah didata (Schiermeier, 2015; Setiawan et al., 2017). Faktor perubahan suhu air laut seringkali dihubungkan dengan pemanasan global. Hewan karang termasuk fauna dengan toleransi perubahan suhu yang rendah yaitu berkisar $1^{\circ} \mathrm{C}-1,5^{\circ} \mathrm{C}$ (Baker et al., 2008; Setiawan et al., 2017). 


\section{PERISTIWA CORAL BLEACHING YANG PERNAH TERJADI DI INDONESIA}

\section{Bali}

Perairan Bali memiliki terumbu karang yang luas dan tersebar hampir di seluruh garis pantai Pulau Bali. Tahun 2015-2016 merupakan tahun terpanas sepanjang sejarah, karena intensitas El Nino yang lebih tinggi dibandingkan dengan El Nino tahun 1997 (Zhai, 2017; Nuryana et al., 2018). Sehingga, perlu adanya pemantauan yang cepat dan efisien untuk kejadian bleaching terumbu karang. Analisis potensi peristiwa pemutihan terumbu karang yang dilakukan oleh Nuryana et al. (2018), menggunakan pemanfaatan citra satelit untuk menduga suhu permukaan laut (SPL). Saat ini, National Ocean Atmospheric Administrations (NOAA) melalui program Coral Reef Watch (CRW) telah memproduksi peta potensi pemutihan karang yang disebut Hotspot (HS). Nilai yang digunakan untuk pemetaan potensi pemutihan karang mengacu pada lamanya sebuah Hotspot mendiami suatu perairan dapat diketahui dengan nilai Degree Heating Week (DHW). Menurut Liu et al. (2014) dalam Strong et al. (2011) dalam Eakin (2010) dalam Nuryana et al. (2018), DHW disebut juga sebagai indeks pemutihan karang yang digunakan untuk memetakan potensi pemutihan karang dan mengungkap kejadian pemutihan karang.

Beberapa lokasi seperti daerah pariwisata Bali Hai, Pelabuhan Buyuk, Desa Suana dan Pantai Kristal Bay di Perairan Nusa Penida mengalami pemutihan karang. Hal itu terjadi karena adanya peningkatan di suhu permukaan laut (SPL). Pemantauan yang dilakukan oleh
Coral Triangle Center (CTC) pada 1 Maret 2016 menunjukkan bahwa wilayah daerah pariwisata Bali Hai telah terjadi pemutihan karang sebesar 30\% dengan kematian karang sebesar 7\% dan sisanya masih dalam keadaan sehat. Karang yang sehat menunjukkan karang mampu bertahan dari peristiwa pemutihan karang (Nuryana et al., 2018).

\section{Natuna}

Hot spots diperkirakan telah menyebabkan terjadinya pemutihan dan kematian terumbu karang di Perairan Laut Natuna bagian Selatan (Rudi, 2012). Hot spot terbentuk akibat adanya kenaikan Suhu Permukaan Laut (SPL). Rudi (2012) mengatakan bahwa pemutihan karang massal di Perairan Laut Natuna bagian Selatan diperkirakan terjadi pada pertengahan tahun 2010 (Gambar 2). Namun, pengambilan data dilakukan pada bulan November 2010, sehingga rata-rata jumlah koloni yang mengalami pemutihan cukup rendah, berkisar 1-7 koloni/ transek. Hasil tersebut berhubungan dengan suhu permukaan laut yang sudah kembali normal dari pertengahan hingga akhir tahun 2010 . Sehingga, karang yang masih bertahan hidup dan memiliki jaringan lunak berangsur pulih dari pemutihan. Namun, sisa karang yang mati akibat pemutihan terlihat telah ditumbuhi makro alga.

\section{Taman Wisata Perairan (TWP) Gili Matra, Nusa Tenggara Barat}

Menurut Nuryana et al. (2018), tahun 2015-2016 menjadi tahun terpanas sepanjang sejarah. Intensitas El Nino pada saat itu lebih tinggi dibandingkan dengan intensitas El Nino tahun 1987-1997 (Zhai, 2017; Nuryana et al., 2018). Hal itu menyebabkan beberapa daerah di Perairan Indonesia mengalami perubahan suhu per- 

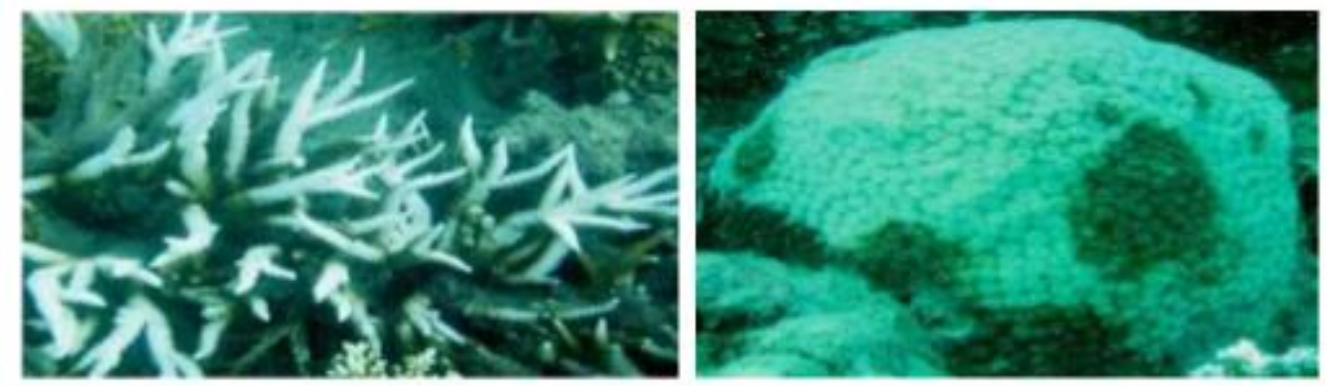

Gambar 2. Coral Bleaching pada karang Acropora dan Diploastrea di Laut Natuna bagian selatan (Rudi, 2012).

mukaan laut seperti di Aceh, Karimunjawa, Lombok, Sulawesi, dan daerah lainnya, termasuk di TWP Gili Matra (Pardede et al., 2016 dalam Setiawan et al., 2017).

TWP Gili Matra yaitu salah satu kawasan konservasi perairan yang terletak di bagian Utara Pulau Lombok. TWP Gili Matra memiliki hamparan terumbu karang seluas 227,65 Ha. Wildlife Conservation Society (WCS) dan BKKPN pada tahun 2012 melakukan kajian ekologi di TWP Gili Matra. Kajian tersebut dilakukan hingga pertengahan tahun 2016. Hasil kajian menunjukkan bahwa TWP Gili Matra terkena pemutihan karang. Hal itu terjadi karena karang yang tidak dapat mentoleransi kenaikan suhu perairan. Penurunan kualitas ekosistem terumbu karang yang terjadi di TWP Gili Matra berasal dari perubahan iklim global yang menyebabkan pemutihan karang masal (Setiawan et al., 2017). Namun, terdapat beberapa jenis karang muda yang mampu bertahan dari peristiwa tersebut. Hal itu dapat memberikan perubahan struktur komunitas karang di TWP Gili Matra dari sebelumnya secara substansial (Obura et al., 2017 dalam Setiawan et al., 2017).

\section{CORAL BLEACHING, KARANG HIDUP ATAU MATI?}

Kondisi karang yang mengalami pemutihan atau bleaching berbeda dengan kondisi karang yang sudah mati. Karang yang mengalami bleaching menandakan kondisi yang sekarat karena keluarnya alga zooxanthellae (symbiodinium) dari jaringan karang. Namun, karang yang terkena bleaching masih dapat pulih atau recovery. Karang dalam kondisi bleaching dapat menerima penempelan zooxanthella kembali (Hughes et al., 2006; Douglas, 2003 dalam Setiawan et al., 2017). Namun, jika tidak ada zooxanthella yang menempel dalam kurun waktu tertentu, karang dapat mengalami kematian. Rekrutmen karang muda memiliki peran penting dalam proses pemulihan karang setelah bleaching. Struktur komunitas karang dapat berubah dari sebelumnya secara substansial oleh jenis karang muda yang mampu bertahan dan pulih dari pemutihan karang (Obura et al., 2017 dalam Setiawan et al., 2017).

Proses pemulihan luka pada karang sebelumnya dianggap sebagai proses energi yang tidak membutuhkan cakupan koloni yang luas (Bak \& Steward-van Es, 1980; Meesters dan Bak, 1993; Meesters et al., 1997 dalam Fine et al., 2002). Namun, beberapa tahun terakhir ditemukan bahwa luka pada karang dapat mengaktifkan pengangkutan fotoasimilasi intra-koloni yang tertuju ke jaringan yang terluka (Oren et al., 1997; 1998, dalam Fine et al., 2002). Sumber daya yang diperlukan untuk pemulihan luka pada karang dapat berasal 
dari polip dan hewan asosiasi di sekitarnya. Oren et al. (2001) dalam Fine et al., (2002) mengatakan bahwa jangkauan sumber translokasi menyesuaikan dengan ukuran dan bentuk dari luka yang ditimbulkan.

Mortalitas atau kematian koloni karang yang terjadi akibat peristiwa coral bleaching umumnya menimbulkan bidang perlukaan pada permukaan karang. Luka tersebut sebagian atau seluruhnya masih dikelilingi oleh jaringan hidup yang tersisa (Jackson \& Coates, 1986 dalam Meesters \& Bak, 1993). Luka yang dapat menjadi pemutihan pada karang tersebut dapat menjadi permanen jika selama masa pemulihannya terus mengalami hambatan atau bersaing dengan organisme lain. Namun, tidak jarang suatu koloni dapat kembali sehat seperti semula melalui pemulihan jaringan dan kerangka (Loya, 1976; Bak et al., 1977; Bak dan Stewardvan Es, 1980; Bak, 1983 dalam Meesters \& Bak, 1993). Proses pemulihan membutuhkan energi yang memengaruhi pertumbuhan (Bak, 1983 dalam Meesters \& Bak, 1993), reproduksi (Rinkevich \& Loya, 1989 dalam Meesters \& Bak, 1993) dan daya tahan terumbu karang tersebut. Proses regenerasi atau pemulihan dapat efektif bila lingkungan sekitarnya mendukung dan suhu permukaan laut kembali stabil.

\section{UPAYA PEMULIHAN TERUMBU KARANG}

Iyam (2007) menjelaskan bahwa upaya penanggulangan dan pengelolaan terumbu karang yang rusak telah dilakukan sejak tahun 1998, namun belum menunjukkan hasil yang baik. Bahkan, ancaman terhadap kerusakan terumbu karang di Indonesia terus meningkat. Oleh karena itu, revisi pola pengelolaan terumbu karang harus dilakukan dengan melibatkan pemerintah dan masyarakat lokal.

Umumnya cara yang dilakukan untuk mengatasi kerusakan terumbu karang yaitu dengan membentuk kawasan konservasi perairan dan teknologi rehabilitasi atau pemulihan seperti terumbu karang buatan dan transplantasi karang. Tujuan utama transplantasi terumbu karang yaitu untuk meningkatkan tutupan karang hidup, keanekaragaman hayati dan keunikan topografi karang (Soedharma dan Arafat, 2006; Subhan et al., 2014). Teknik transplantasi karang dilakukan melalui pencangkokkan atau pemotongan karang hidup, lalu diletakkan di tempat lain atau pada ekosistem yang telah rusak (Sadarun, 1999; Yunus et al., 2013). Transplantasi karang memanfaatkan kemampuan reproduksi karang secara aseksual (Yunus et al., 2013).

Transplantasi yang diterapkan di Indonesia saat ini memiliki berbagai macam metode. Beberapa metode yang digunakan yaitu metode rak jaring dan substrat (Subhan et al., 2008 dalam Subhan et al., 2014), beton (Johan, 2012 dalam Subhan et al., 2014), jaring dan pecahan (Fadli, 2008 dalam Subhan et al., 2014), substrat alami (Haris, 2012 dalam Subhan et al., 2014), modifikasi menggunakan biorock karang (Zamani et al., 2009 dalam Subhan et al., 2014), metode tali (Yunus et al., 2013), dan mikrofragmentasi (Page et al., 2018). Adapun upaya rehabilitasi terumbu karang menggunakan karang buatan yaitu dengan Artificial Patch Reefs (APR) (Rinkevich, 2005; Avidgor, 2006; Munasik et al., 2017). Berikut ini merupakan penjelasan dari beberapa jenis transplantasi terumbu karang, yaitu: 


\section{Mikrofragmentasi}

Mikrofragmentasi merupakan salah satu teknik dari proses rehabilitasi terumbu karang dengan memotong karang menjadi bagian-bagian yang kecil (Gambar 3). Teknik mikrofragmentasi telah menjadi alat restorasi terumbu karang yang layak (Rinkevich, 1995; Epstein et al., 2003; Rinkevich, 2005; Page et al., 2018). Teknik ini dapat dilakukan pada pembibitan karang skala in situ (di laut) dengan jumlah kecil. Koloni karang akan terbagi menjadi potongan-potongan kecil dan dibiarkan tumbuh dalam ukuran tersebut. Setelah mulai tumbuh, karang hasil mikrofragmen dipantau untuk pertumbuhan dan kelangsungan hidupnya. Banyak penelitian yang telah membuktikan bahwa teknik hasil mikrofragmentasi efektif untuk pembibitan (Herlan \& Lirman, 2008; Shaish et al., 2008; Levy et al., 2010; Page et al., 2018) dan fase penanaman rehabilitasi koloni karang (Putchim \& Thongtham, 2008; Shaish et al., 2010; Hollarsmith, 2012; Page et al., 2018).

\section{Metode Tali}

Soong \& Chen (2003) dalam Yunus et al. (2013), mengatakan bahwa semakin panjang ukuran suatu fragmen karang, maka akan semakin cepat laju pertumbuhannya. Namun, pengambilan fragmen karang yang terlalu panjang dapat menyebabkan eksploitasi yang berlebihan pada koloni karang induk. Sehingga, pengambilan fragmen karang harus pada ukuran yang tepat dan sesuai untuk transplantasi. Pertumbuhan karang selalu menuju ke arah datangnya matahari. Posisi penanaman potongan karang secara horizontal pada metode tali menjadi posisi optimal karena karang dapat tumbuh ke segala arah (Gambar 4) (Soedharma \& Arafat, 2008; Yunus et al., 2013). Hasil transplantasi metode gantung menunjukkan pertumbuhan yang lebih baik dibandingkan dengan metode transplantasi tanam tempel (Yunus et al., 2013).

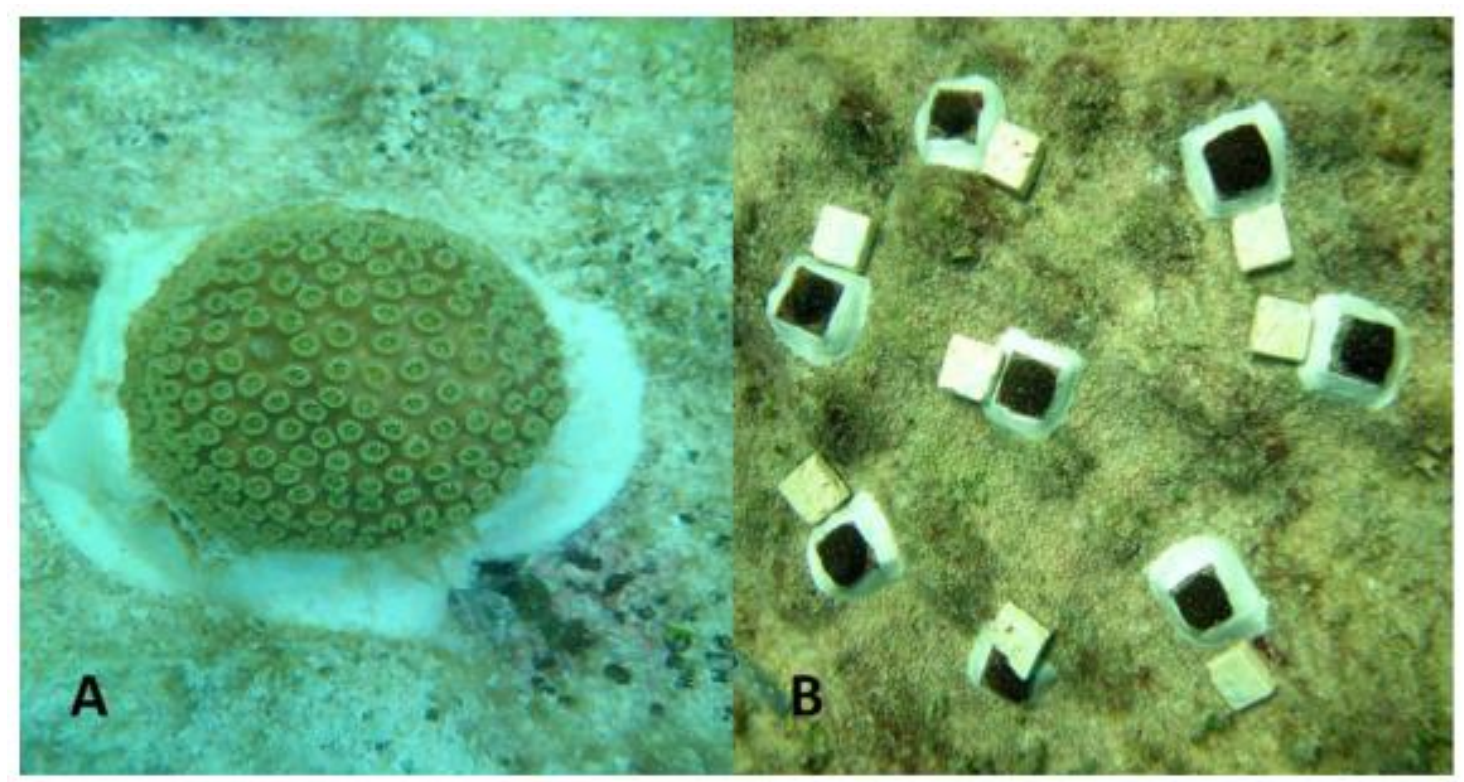

Gambar 3. Transplantasi teumbu karang dengan Teknik Mikrofragmentasi (Page et al., 2018). 


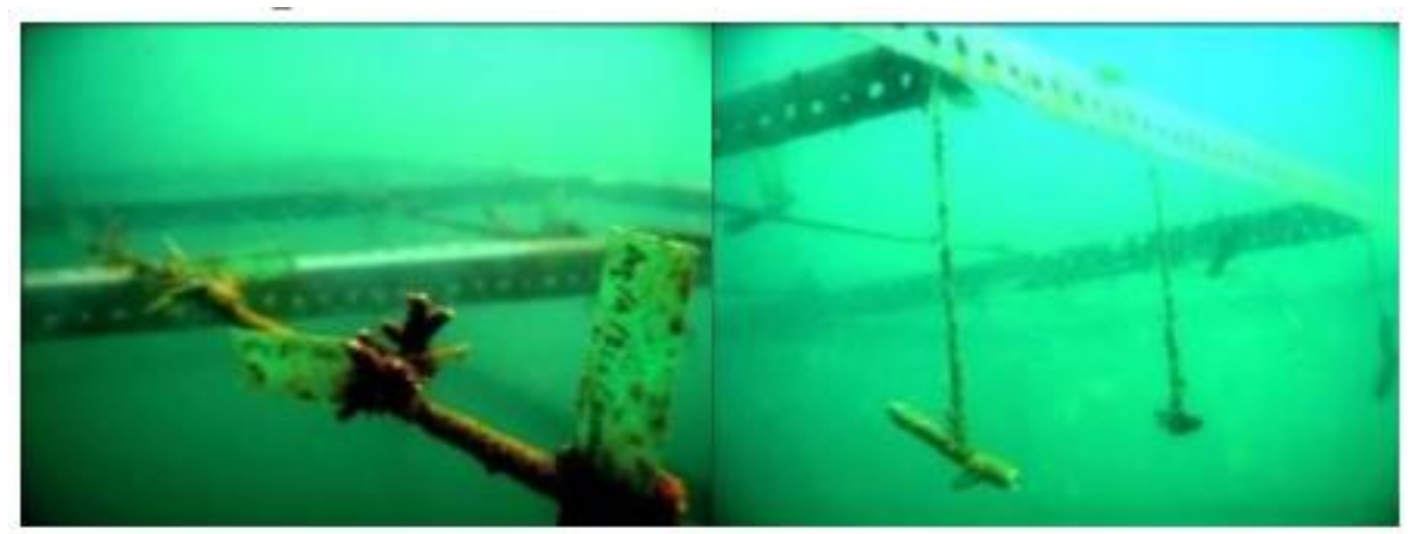

Gambar 4. Transplantasi teumbu karang dengan Metode Tali (Yunus et al., 2013).

\section{Artificial Patch Reefs (APR)}

Artificial Patch Reefs (APR) adalah salah satu metode yang dapat digunakan dalam upaya rehabilitasi atau pemulihan terumbu karang (Rinkevich, 2005; Avidgor, 2006 dalam Munasik et al., 2017). Berbagai macam APR telah dikerahkan untuk keperluan yang berbeda-beda yaitu sebagai rumah ikan, wisata bahari dan rehabilitasi terumbu karang. Bahan yang digunakan dalam pembuatan konstruksi APR terdiri dari bahan alami maupun bahan buatan. Bahan alami yang digunakan dalam pembuatan konstruksi APR umumnya terbuat dari batu, bambu dan kayu. Sedangkan bahan buatan yang digunakan dalam konstruksi APR umumnya terbuat dari ban, balok beton, bekas kendaraan, besi, dan lainnya (Gambar 5) (Baine, 2001 dalam Munasik et al., 2017).
APR yang diterapkan dalam rehabilitasi terumbu karang di Indonesia umumnya menggunakan material balok beton dengan bentuk seperti piramida, pipa, batang, loop dan kubik (Munasik et al., 2017). Variasi konstruksi dan material bertujuan untuk menggantikan atau meniru terumbu karang alami, sehingga dapat memikat jenis-jenis organisme laut untuk hidup dan menetap (Pardede, 2012 dalam Prayoga et al., 2019). Menurut (Rinkevich, 2005; Avidgor, 2006 dalam Munasik et al., 2017), metode transplantasi karang dapat diaplikasikan pada APR untuk mendukung rehabilitasi terumbu karang. Kombinasi penggunaan APR dengan transplantasi karang menjadi alternatif dalam mendukung keberhasilan rehabilitasi terumbu karang (Munasik, 2008 dalam Munasik et al., 2017).
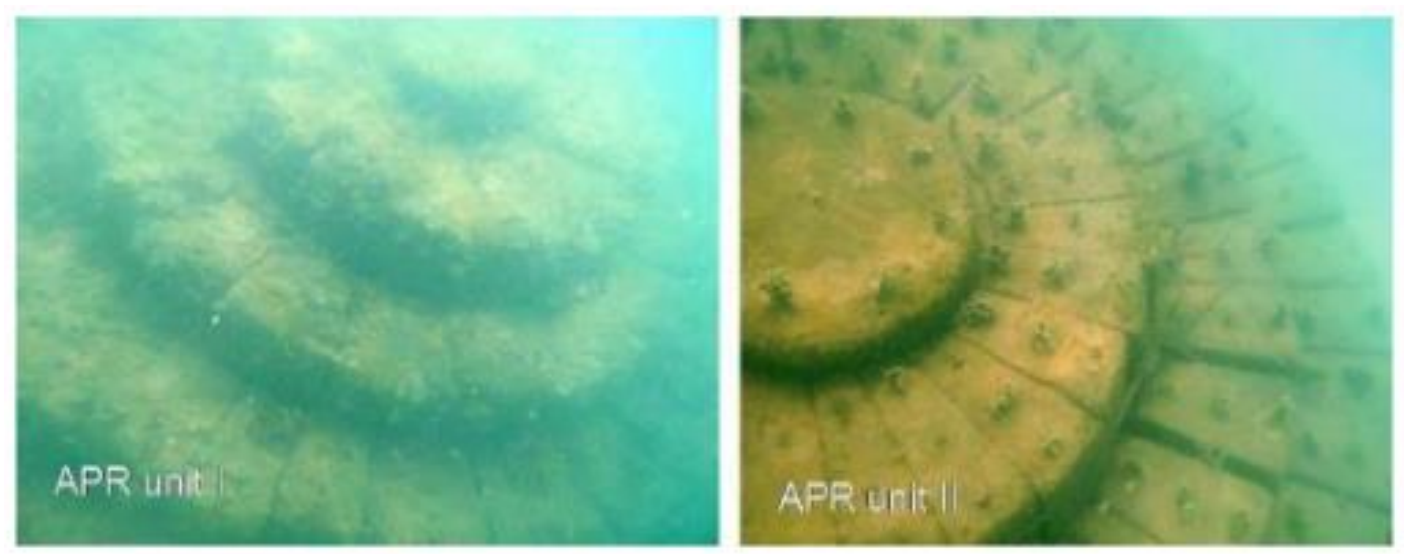

Gambar 5. Artificial Patch Reefs (APR) berbentuk piramida melingkar (Munasik et al., 2017) 


\section{PENUTUP}

Peristiwa pemutihan karang atau coral bleaching merupakan dampak dari karang yang mengalami tekanan atau stres lingkungan. Peristiwa pemutihan karang umumnya disebabkan oleh adanya perubahan Suhu Permukaan Laut (SPL). Karang yang mengalami bleaching menandakan kondisi yang sekarat karena keluarnya alga zooxanthellae (symbiodinium) dari jaringan karang. Namun, karang yang mengalami bleaching masih dapat pulih atau recovery. Karang dalam kondisi bleaching masih dapat menerima penempelan zooxanthellae kembali dan dapat memperbaiki jaringan karang yang rusak akibat peristiwa tersebut. Rekrutmen atau penerimaan karang muda memiliki peran penting dalam proses pemulihan karang setelah bleaching. Proses pemulihan dari peristiwa pemutihan karang dapat efektif apabila lingkungan di sekitarnya mendukung dan suhu permukaan laut kembali stabil.

\section{DAFTAR PUSTAKA}

Ainsworth, T. D., Heron, S. F., Ortiz, J. C., Mumby, P. J., Grech, A., Ogawa, D., C. Ekain M., \& Leggat. W. (2016). Climate change disable coral bleaching protection on the Great Barrier Reef. RESEARCH, 352(6283): 338-342.

Aldyza, N \& Afkar, A. (2015). Analisis genus dan penyakit karang di perairan Pulau Tuan Kecamatan Peukan Bada Kabupaten Aceh Besar. Jurnal Biotik, 3(2): 107-115.

Ambariyanto, Wijayanti, D. P., Munasik, Purnama, P. E., Hudatwi, M., Ernawati N. M., \& Ko'ou, A. Y. (2018). Are zooxanthellae really sensitive? Response of zooxanthellae size exposed to several pollutants.
Indonesian Journal of Marine Science, 23(1): 19-24.

Fachrurrozie, A., Patria, M. P., \& Widiarti, R. (2012). Pengaruh perbedaan intensitas cahaya terhadap kelimpahan zooxanthella pada karang bercabang (Marga: Acropora) di perairan pulau ari, Kepulauan Seribu. Jurnal Akuatika, 3(2): 115124.

Fine, M., Oren, U., \& Loya, Y. (2002). Bleaching effect on regeneration and resource translocation in the coral Oculina patagonica. Marine Ecology Progress Series, 234: 119-125.

Iyam. (2007). Pemeliharaan Terumbu Karang, Seri Flora dan Fauna. TITAN ILMU: Bandung, 104 pp.

Meesters, E. H. \& Bak, R. P. M. (1993). Effects of coral bleaching on tissue regeneration potential and colony survival. Marine Ecology Progress Series, 96: 189-198.

McClanahan, T. R., Baird A. H., Marshall, P. A., \& Toscano, M. A. (2004). Comparing bleaching and mortality responses of hard corals between southern Kenya and the Great Barrier Reef, Australia. Marine Pollution Bulletin, 48: 327-335.

Munasik, M., Sugiyanto, S., D. Sugianto, N., \& Sabdono, A., (2017). Reef development on Artificial Patch Reefs in shallow water of Panjang Island, Central Java. IOP Conference Series: Earth and Environmental Science, 116(3): 1-9.

Nuryana, J., Hendrawan, I. G., \& Karim, W. (2018). Pendugaan kejadian pemutihan karang berdasarkan analisis Suhu Permukaan Laut (SPL) tahun 2015-2016 di Perairan Bali. Journal of Marine and Aquatic Sciences, 4(2): 286-296.

Page, C. A., Muller, E. M., \& Vaughan, D. E. (2018). Microfragmenting for the successful restoration of slow growing massive corals. Ecological Engineering, 123: 86-94. 
Papu, A. (2011). Kondisi tutupan terumbu karang Pulau Kapoposang, Kabupaten Pangkajene Kepulauan, Provinsi Sulawesi Selatan. Jurnal Ilmiah Sains, 11(1): 6-12.

Prayoga, B., Munasik, \& Irwani, I. (2019). Perbedaan metode transplantasi terhadap laju pertumbuhan Acropora aspera pada Artificial Patch Reefs di Pulau Panjang, Jepara. Journal of Marine Research, 8(1): 1-10.

Rudi, E. (2012). Pemutihan karang di Perairan Laut Natuna Bagian Selatan tahun 2010. Biospecies, 5(1): 1-7.

Ramadhan, A., Lindawati, \& Kurniasari, N. (2016). Nilai ekonomi ekosistem terumbu karang di Kabupaten Wakatobi. Jurnal Sosial Ekonomi Kelautan dan Perikanan, 11(2): 133146.

Sari, N. W. P. (2016). Coral reef, penyerap atau penghasil carbon?. Oseana, XL1(2): 32-40.

Setiawan, F., Mutaqqin, A., Tarigan, S. A., Muhidin, Hotmariyah, Sabil, A., \& Pinkan, J. (2017). Pemutihan karang akibat pemanasan global tahun 2016 terhadap ekosistem terumbu karang: Studi kasus di TWP Gili Matra (Gili Air, Gili Meno dan Gili Trawangan) Provinsi NTB. Journal of Fisheries and Marine Science, 1(2): 39-54.

Siringoringo, R. M. (2007). Pemutihan karang dan beberapa penyakit karang. Oseana, 32(4): 29-37.

Subhan, B., Madduppa, H., Arafat, D., \& Soedharma, D. (2014). Bisakah transplantasi karang perbaiki ekosistem terumbu karang?. Risalah Kebijakan Pertanian dan Lingkungan, 1(3): 159-164.

Surinati, D. (2008). Perubahan iklim: Dampak dan solusinya. Oseana, 33(3): 15-26.

Veron, J. E. N. (2000). Coral of The World, Vol 1. Australian Institute of Marine Science: Townsville, $463 \mathrm{pp}$.

Yunus, B. H., Wijayanti, D. P., \& Sabdono, A. (2013). Transplantasi karang Acropora aspera dengan Metode Tali di Perairan Teluk Awur, Jepara. Buletin Oseanografi Marina, 2: 2228. 